\title{
Formulasi dan Uji Stabilitas Fisik Krim Ekstrak Daun Jati (Tectona grandis L.) Sebagai Pewarna Rambut
}

\section{Formulation and Physical Stability Test of Cream Containing Teak Leaf (Tectona grandis L.) Extract As Hair Dye Agent}

\author{
Arif Budiman', Azhara Regita Vegy Miranda², Arini Syarifah* \\ Fakultas Farmasi, Universitas Muhammadiyah Purwokerto \\ Jl. Raya Dukuhwaluh, Dukuhwaluh, Kembaran, Purwokerto 53182, Indonesia \\ *email: arinisyarifah@ump.ac.id \\ (Tanggal diterima : 16-02-2020, Tanggal disetujui : 27-04-2020)
}

\section{INTISARI}

Para-Phenylenediamine (PPD) merupakan pewarna rambut sintetis yang banyak digunakan pada produk pewarna rambut tetapi merupakan sensitizer yang sangat kuat dapat menyebabkan reaksi kontak alergi yang parah. Oleh karena itu, dilakukan pengembangan formulasi pewarna rambut dengan bahan aktif yang diperoleh dari daun jati. Daun jati mengandung antosianin yang berperan sebagai zat pewarna.

Daun jati diekstraksi menggunakan metode ultrasound assisted extraction dengan pelarut etanol 70\% dan frekuensi $40 \mathrm{kHz}$ selama 30 menit. Hasil ekstraksi kemudian diuapkan menggunakan rotary evaporator. Formulasi pewarna rambut dibuat menggunakan ekstrak daun jati dengan konsentrasi 10 (F1); 12,5 (F2); dan 15\% (F3). Evaluasi fisik sediaan krim meliputi uji organoleptik, homogenitas, $\mathrm{pH}$, viskositas dan daya sebar. Uji stabilitas fisik dilakukan dengan metode cycling test.

Krim pewarna rambut ekstrak daun jati memberikan warna coklat kemerahan terhadap rambut. Hasil homogenitas menunjukan semua formula homogen. $\mathrm{pH}$ masing-masing formula adalah 6,297 $\pm 0,118$ (F1), 6,770 $\pm 0,010$ (F2) dan 5,917 \pm 0,045 (F3). Hasil viskositas masing-masing formula adalah $11.400 \pm 268,514$ (F1), $11.463 \pm 501,232$ (F2) dan $11.687 \pm 283,078 \mathrm{cPs}$ (F3). Uji daya sebar menunjukan hasil 5,326 $\pm 0,303$ (F1), 5,072 $\pm 0,760$ (F2), dan 5,050 $\pm 0,092 \mathrm{~cm}$ (F3). Hasil uji stabilitas fisik berdasarkan nilai viskositas, $\mathrm{pH}$ dan daya sebar menunjukan F3 merupakan formula yang paling stabil.

Kata kunci: Daun jati; krim; pewarna rambut; stabilitas fisik

\begin{abstract}
Para-Phenylenediamine is a synthetic hair dye that is widely used in hair dye products and has very strong sensitizer that can cause severe allergic reactions. Solution of this problem are the development of hair dye formulations with active ingredients obtained from teak leaves. Teak leaves contains anthocyanin which acts as a coloring agent.

Teak leaves were extracted using the ultrasound assisted extraction method with ethanol $70 \%$ with a frequency in $40 \mathrm{kHz}$ for 30 minutes then evaporated using a rotary evaporator. Formulation of hair dye using concentration extract : 10 (F1); 12.5 (F2); and 15\% (F3). Physical evaluation of cream hair dye are organoleptic, homogeneity, $\mathrm{pH}$, viscosity and diffusion test. Stability test using cycling test method.

Teak leaf extract cream gives a reddish brown color to the hair. Homogeneity test show all formulas are homogeneous. pH test result of each formula was $6.297 \pm 0.118$ (F1), $6.770 \pm 0.010$ (F2) and $5.917 \pm 0.045$ (F3). The viscosity value of each formula was 11,400 $\pm 268,514$ (F1), 11,463 $\pm 501,232$ (F2) and $11,687 \pm 283,078$ cPs (F3). Spreadability test showed long spreadability of each formula was $5.326 \pm 0.303$ (F1), 5,072 \pm 0.760 (F2), and 5,050 $\pm 0.092 \mathrm{~cm}$ (F3). The stability test results show that F3 is the most stable formula.
\end{abstract}

Keyword : Teak leaf; cream; hair dye; physical Stability 


\section{PENDAHULUAN}

Pewarna rambut adalah sediaan kosmetik yang digunakan dalam tata rias rambut baik untuk mengembalikan warna asalnya/menutupi atau untuk membuat warna lain (Badan POM, 2008). Salah satu bahan kimia untuk pewarna rambut adalah Para-Phenylenediamine (PPD) (1). PPD merupakan pewarna rambut yang banyak digunakan sebesar $70 \%$ dari semua produk pewarna rambut. Namun, PPD menjadi sensitizer yang sangat kuat, dengan kemampuan untuk menyebabkan reaksi kontak alergi yang parah (2). The North American Contact Dermatitis Research Group melaporkan tingkat prevalensi alergi PPD pasien pada uji Patch Test sebesar $5 \%$ pada tahun 2005 - 2006 dan meningkat menjadi sebesar 5,5\% pada tahun 2009 - 2010 (1). Di Indonesia, dalam surat edaran BPOM Nomor. HK.05.02.1.42.09.16.1563 tahun 2016 disebutkan turunan PPD yaitu 2Methoxymethyl-p-Phenylenediamine dan 2-Methoxymethyl-p-Phenylenediamine sulfate termasuk dalam bahan yang dilarang dalam kosmetika. Zat kimia sebagai pewarna sintetis lainnya yaitu Rhodamin B. Pewarna rhodamin B secara topikal/luar tubuh, bisa menyebabkan iritasi kulit, risiko kanker dan dalam konsentrasi tinggi bisa menyebabkan kerusakan hati (3).

Pemakaian zat warna alami dalam sediaan kosmetika sebagai suatu solusi sangat dibutuhkan karena efek sampingnya yang relatif kecil. Salah satu tanaman yang dikenal memiliki zat warna alami adalah daun jati. Daun jati mangandung pigmen alami antosianin yaitu zat sianidin yang cukup tinggi sehingga dapat memberikan warna merah pada preparat $(4 ; 5)$. Pemberian ekstrak daun jati dosis 2000 dan $5000 \mathrm{mg} / \mathrm{kg}$ BB tidak memberikan efek toksik pada organ hati, ginjal, usus halus, jantung, lambung, limpa, dan paru. Daun jati selama ini hanya digunakan untuk pewarna dalam pengolahan makanan gudeg dan telur merah, pewarna kain kapas, indikator alternatif titrasi asam-basa $(6 ; 7 ; 8)$. Hasil penelitian oleh Arofiani (9) menunjukkan bahwa ekstrak etanol 96\% daun jati menghasilkan warna cokelat pada rambut dengan konsentrasi 10\%. Semakin besar konsentrasi ekstrak pucuk daun jati, maka warna rambut yang dihasilkan semakin gelap.

Oleh karena itu, dalam penelitian ini akan membuat sediaan pewarna rambut dari ekstrak tanaman daun jati dalam sediaan krim. Ekstrak daun jati diformulasikan dalam bentuk krim karena belum ada penelitian krim pewarna rambut ekstrak daun jati. Selain itu pemilihan krim dikarenakan krim lebih menunjukkan keunggulan yaitu dari aspek kelembutan, kelunakan, dan kenyamanan, serta lebih stabil jika dibandingkan dengan bentuk sediaan lain seperti sediaan cair\& gel (10).

\section{METODE PENELITIAN}

\subsection{ALAT DAN BAHAN}

Alat-alat yang digunakan untuk ekstraksi adalah ultrasonic bath (Branson), rotary evaporator (IKA RV 10), blender ayakan nomor mesh 40 dan kertas saring.

Alat yang digunakan untuk formulasi adalah pipet tetes, pipet volume, corong, alat gelas mortir, stamper, $\mathrm{pH}$ meter (Ohaus) dan viskometer (Brookfield), Bahan yang digunakan untuk ekstraksi adalah daun jati dan etanol 70\%, Bahan yang digunakan formulasi adalah karbomer, natrium lauril sulfat, cocamide DEA, natrium 
sulfit, EDTA, ammonia, TEA, akuades, setil alkohol, asam stearat, hidrogen peroksida, pereaksi $\mathrm{AlCl}_{3}$, ammonia solution, n-butanol, silica gel GF254 dan asam asetat glacial.

Tabel 1. Komposisi Formula Sediaan Krim Ekstrak Daun Jati Dengan Berbagai Perbandingan Konsentrasi Ekstrak

\begin{tabular}{|l|c|c|c|c|}
\hline \multirow{2}{*}{ Nama Bahan } & \multicolumn{4}{c|}{ Jumlah \% (b/b) } \\
\cline { 2 - 5 } & F1 & F2 & F3 & KN \\
\hline Ekstrak daun jati & 2 & 2,5 & 3 & - \\
\hline Karbomer & 0,3 & 0,3 & 0,3 & 0,3 \\
\hline Natrium sulfit & 0,06 & 0,06 & 0,06 & 0,06 \\
\hline EDTA & 0,04 & 0,04 & 0,04 & 0,04 \\
\hline Ammonia & 1,8 & 1,8 & 1,8 & 1,8 \\
\hline Hidrogen peroksida & 4 & 4 & 4 & 4 \\
\hline Air suling & 9,1 & 8,6 & 8,1 & 11,1 \\
\hline Natrium lauril sulfat & 0,3 & 0,3 & 0,3 & 0,3 \\
\hline Cocamide DEA & 0,5 & 0,5 & 0,5 & 0,5 \\
\hline Setil alkohol & 1 & 1 & 1 & 1 \\
\hline Asam stearat & 0,4 & 0,4 & 0,4 & 0,4 \\
\hline TEA & 0,5 & 0,5 & 0,5 & 0,5 \\
\hline
\end{tabular}

\subsection{CARA KERJA \\ Proses Ekstraksi \\ Determinasi Tanaman}

Dilakukan determinasi tanaman untuk menetapkan kebenaran sampel yang digunakan dalam penelitian. Determinasi dilakukan di Laboratorium Lingkungan, Fakultas Biologi, Universitas Jenderal Soedirman.

\section{Pengolahan Simplisia}

Daun jati segar sebanyak $1 \mathrm{~kg}$ dicuci bersih dengan air mengalir dan ditiriskan. Kemudian dikeringkan dengan sinar matahari. Simplisia kering dihaluskan dengan blender dan diayak menggunakan ayakan berukuran 40 mesh dan diperoleh simplisia halus.

\section{Ekstraksi}

300 gram daun jati yang telah kering dan halus ditambahkan pelarut etanol $70 \%$ dengan perbandingan rasio bahan pelarut 1:5 kemudian diekstraksi dengan metode ultrasound assisted extraction (UAE). Pelarut etanol yang sudah ditambahkan daun jati ditempatkan pada ultrasonic bath dengan menggunakan frekuensi $40 \mathrm{kHz}$ selama 30 menit. Hasil ekstraksi disaring dan filtratnya diuapkan dengan rotary evaporator dengan suhu $40^{\circ} \mathrm{C}$ dan kecepatan $100 \mathrm{rpm}$ hingga diperoleh ekstrak etanolik daun jati (11).

\section{Identifikasi Ekstrak}

Identifikasi ekstrak dilakukakn dengan menggunakan metode Kromatografi Lapis Tipis (KLT). Ekstrak daun jati sebanyak 0,5 g dicampur dengan $5 \mathrm{ml}$ etanol $70 \%$. Fase diam yang digunakan adalah silika gel GF254 dan fase gerak campuran n-butanol : asam asetat : air (4:1:5). Kemudian memasukan silika gel GF254 ke dalam oven suhu $110^{\circ} \mathrm{C}$ selama 10 menit. $3 \mu \mathrm{l}$ sample ditotolkan pada lempeng KLT. 
Elusi dengan fase gerak yang sudah dijenuhkan selama 15 menit dengan jarak rambat 8,5 cm. Keringkan lempeng tersebut diudara 10 menit. Amati dengan sinar biasa dan dengan sinar ultraviolet $366 \mathrm{~nm}$. Selanjutnya diuapkan dengan amonia. Panaskan pada suhu $110^{\circ} \mathrm{C}$ selama 10 menit. Amati lagi dengan sinar biasa dan dengan sinar ultraviolet $366 \mathrm{~nm}$. Dengan perlakuan yang sama seperti cara kerja di atas dilakukan juga penyemprotan dengan pereaksi AlCl3 (12).

\section{Formulasi Sediaan Krim Ekstrak Daun Jati}

Karbomer ditambah air secukupnya, ditambahkan TEA kemudian diaduk sampai homogen (larutan 1). Natrium lauril sulfat, cocamide DEA, natrium sulfit, EDTA dipanaskan pada suhu $85^{\circ} \mathrm{C}$ sampai larut, kemudian diaduk sampai homogen (larutan 2). Larutan 1 dan larutan 2 dicampur kemudian ditambah ekstrak kental daun jati dan ammonia sampai homogen (larutan 3). Setil alkohol dan asam stearat dipanaskan sampai larut, ditambahkan hidrogen peroksida, lalu campur dengan larutan 3, diaduk sampai homogen. Rancangan formula terdapat pada tabel 1.

\section{Uji Sifat Fisik Krim Ekstrak Daun Jati Uji Organoleptis}

Pengamatan organoleptis meliputi bentuk, warna, dan bau terhadap sediaan pewarna rambut.

\section{Uji Homogenitas}

Krim pada masing-masing formula diambil 1 gram dan dioleskan pada plat kaca, diraba dan digosokkan. Massa krim harus menunjukan susunan homogen yaitu tidak terasa adanya bahan padat pada kaca (13).

\section{Uji Daya Sebar}

Krim ditimbang 1 gram kemudian diletakkan diatas plat kaca dan biarkan satu menit. Diameter sebar krim diukur dan ditambahkan 50 gram beban, diamkan selama satu menit lalu di ukur diameter sebarnya, replikasi dilakukan sebanyak 3 kali (14).

\section{Uji pH}

Sebanyak 0,5 gram krim diencerkan dengan $10 \mathrm{ml}$ aquadest. $\mathrm{pH}$ meter dikalibrasi dengan menggunakan buffer $\mathrm{pH} 4$ dan $\mathrm{pH}$ 7. Kemudian elektroda dicelupkan dalam larutan sampel. Dibiarkan alat menunjukkan harga $\mathrm{pH}$ sampai konstan. Angka yang ditunjukkan pH meter merupakan $\mathrm{pH}$ sediaan (15).

\section{Uji Viskositas}

Pengukuran viskositas dilakukan dengan menggunakan viskometer Brookfield untuk mengetahu tingkat kekentalan dari sediaan. Prosedurnya yaitu dengan memasang spindle No.4 pada alat kemudian dicelupkan kedalam sediaan sampai batas tertentu dan atur kecepatan $50 \mathrm{rpm}$ Pada suhu $\left(25^{\circ} \mathrm{C}\right)$. Tiap masingmasing pengukuran dibaca skalanya ketika jarum merah telah stabil nilai vikositas diperoleh dari hasil perkalian dial reading dengan faktor koreksi khusus pada masing-masing kecepatan spindle (3).

\section{Uji Stabilitas Metode Cycling Test}

Uji ini dilakukan dengan cara menyimpan sediaan krim dimasukkan ke dalam refrigerator pada suhu $4^{\circ} \mathrm{C}$ selama 24 jam, kemudian dimasukkan ke dalam oven pada suhu $40^{\circ} \mathrm{C}$ selama 24 jam sehingga terjadi 1 siklus. Pemeriksaan cycling 
test dilakukan sebanyak 6 siklus (16). Pengamatan hasil cycling test adalah parameter organoleptik, homogenitas, $\mathrm{pH}$, viskositas dan daya sebar disetiap siklusnya.

\section{Pengujian Pewarnaan terhadap Rambut}

Sejumlah rambut yang telah dipucatkan dipotong $10 \mathrm{~cm}$. Kemudian dicuci dengan sampo dan dikeringkan. Sediaan krim ekstrak daun jati dioleskan secara merata lalu didiamkan selama 90 menit. Rambut dicuci dengan sampo dan dikeringkan kembali. Pengamatan dilakukan secara subjektif dan objektif dengan diamati warna yang terbentuk (10). Pengamatan subjektif dilakukan identifikasi warna oleh peneliti dan pengamatan objektif dengan menggunakan alat colour reader $C R-10$.

\section{Analisis Hasil}

Analisis hasil dilakukan secara deskriptif untuk pengamatan organoleptis dan homogenitas. Hasil pengukuran $\mathrm{pH}$, viskositas, daya sebar, daya lekat serta uji stabilitas cycling test dilakukan uji normalitas data. Jika data terdistribusi normal selanjutnya dilakukan uji anova satu arah untuk pengukuran $\mathrm{pH}$, viskositas, daya sebar dan daya lekat. Untuk cycling test, jika data terdistribusi normal dilakukan uji anova dua arah.Kemudian dilanjutkan dengan Post hoc Test Tukey untuk mengetahui perbedaan tersebut.

\section{HASIL DAN PEMBAHASAN}

\section{1. Proses Ekstraksi Determinasi Tanaman}

Determinasi bertujuan untuk mengetahui atau memastikan kebenaran identitas tanaman yang akan diteliti, untuk menghindari kesalahan dalam pengumpulan bahan penelitian. Hasil dari determinasi tersebut menyatakan bahan tanaman yang akan digunakan dalam penelitian ini adalah benar-benar tanaman daun jati dari familia Lamiaceae spesies Tectona grandis, L .

\section{Ekstraksi Daun Jati}

Salah satu senyawa flavonoid yang terdapat di ekstrak daun jati yang dapat memunculkan warna adalah antosianin. Antosianin terletak di intra seluler di dalam vakuola sehingga untuk memudahkan penetrasi dan difusi antosianin ke dalam pelarut dibutuhkan energi yang besar seperti energi pada gelembung kavitasi untuk dapat memecah dinding sel simplisia (17). Oleh karena itu untuk mendapatkan antosisanin maka menggunakan ekstraksi UAE yaitu memanfaatkan gelombang ultrasonik yang ditransmisikan melalui pelarut untuk menyebabkan kavitasi mikro pada sekeliling bahan yang akan diekstraksi sehingga terjadi pemanasan akhirnya melepaskan senyawa ekstrak.

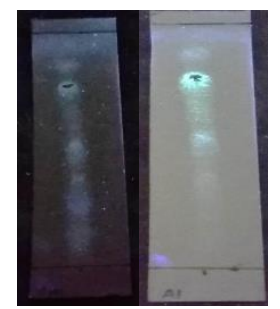

Gambar 1. Bercak setelah disemprot $\mathrm{AlCl}_{3}$ (kiri) dan setelah diuapkan ammonia (kanan) 
Efek mekanik yang ditimbulkan adalah memecah dinding sel tanaman sekaligus meningkatkan transfer massa sehingga senyawa fitokimia yang terkandung di dalam tanaman lebih banyak berdifusi kedalam pelarut (18). Berdasarkan penelitian Sholihah (17), ekstraksi ultrasonik dapat meningkatkan rendemen esktrak sebesar $1,02-2,66 \%$ dan meningkatkan kadar antosianin total sebesar 23-88\% dibandingkan dengan ekstraksi maserasi. Ekstrak kental yang didapat yaitu sebanyak 59,09 gram dengan persentase rendemen sebanyak 19,69\%. Identifikasi Ekstrak

Hasil identifikasi dengan menggunakan metode KLT memberikan hasil adanya bercak warna kuning dan biru (setelah disemprot dengan $\mathrm{AlCl}_{3}$ ) pada gambar 1 dan pada gambar 2 memberikan warna biru menyala (setelah diberi uap Amonia) di bawah lampu UV $366 \mathrm{~nm}$. Hal tersebut menandakan adanya senyawa flavonoid golongan antosianin (19).

\section{2. Formulasi \& Pengujian Sifat Fisik Krim Ekstrak Daun Jati}

Krim pewarna rambut yang diformulasikan tersaji dalam tabel 2 dan gambar 3. Hasil pengujian homogenitas sediaan krim ekstrak daun jati konsentrasi $10 ; 12,5$ ; dan $15 \%$ tidak ditemukan adanya gumpalan atau bahan padat pada plat kaca, sehingga sediaan krim pewarna rambut ekstrak daun jati yang dibuat telah tercampur secara homogen dan memiliki tekstur yang rata dan hasil pengukuran $\mathrm{pH}$ pada tabel 2 menunjukkan bahwa $\mathrm{pH}$ pewarna rambut sesuai dengan kriteria $\mathrm{pH}$ kulit kepala yaitu 5,0 - 9,0.

Data viskositas pada tabel 3 diuji statistik menggunakan One-Way Anova dengan taraf kepercayaan 95\%. Diperoleh hasil statistik yaitu nilai p >0,05 $(0,430)$ artinya tidak ada perbedaan yang bermakna antara kontrol negatif, FI, FII dan FIII. Berdasarkan hasil viskositas dan daya sebar yang diperoleh (Tabel 3), dapat disimpulkan bahwa semakin tinggi konsentrasi ekstrak daun jati yang digunakan dalam sediaan, semakin meningkat viskositas sediaan krim pewarna rambut. Viskositas yang tinggi juga meningkatkan daya sebar dari krim pewarna rambut (20). Pada formula 3 merupakan formula yang memiliki viskositas dan daya sebar yang tinggi.

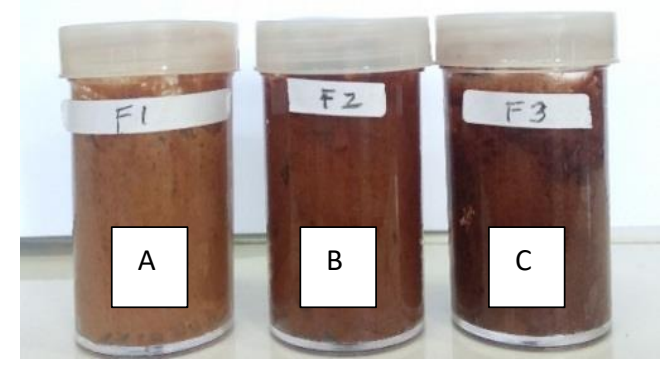

Gambar 2. Hasil Formulasi Krim Ekstrak Daun Jati Dengan Konsentrasi 10\% (A), 12,5\% (B) dan 15\% (C) 
Tabel 2. Hasil Pengamatan Organoleptis Krim Ekstrak Daun Jati

\begin{tabular}{cccc}
\hline Formula & Bentuk & Warna & Bau \\
\hline KN & Semi Padat & Putih & Khas \\
F I & Semi Padat & Cokelat & Khas \\
F II & Semi Padat & Cokelat Muda & Khas \\
F III & Semi Padat & Cokelat Pekat & Khas \\
\hline
\end{tabular}

Tabel 3. Hasil Pengujian Sifat Fisik Krim Ekstrak Daun Jati

\begin{tabular}{cccc}
\hline \multirow{2}{*}{ Formula } & \multicolumn{3}{c}{ Rata-Rata Hasil Pengujian \pm SD (n=3) } \\
\cline { 2 - 4 } & pH rata-rata & Viskositas (cPs) & Daya Sebar (cm) \\
\hline KN & $5,257 \pm 0,146$ & $10.967 \pm 810,082$ & $5,011 \pm 0,140$ \\
F I & $6,297 \pm 0,118$ & $11.400 \pm 268,514$ & $5,326 \pm 0,303$ \\
F II & $6,770 \pm 0,010$ & $11.463 \pm 501,232$ & $5,072 \pm 0,760$ \\
F III & $5,917 \pm 0,045$ & $11.687 \pm 283,078$ & $5,050 \pm 0,092$ \\
\hline
\end{tabular}

Keterangan :

KN : krim pewarna rambut tanpa daun ekstrak jati.

F I : : krim pewarna rambut ekstrak daun jati dengan konsentrasi $10 \%$

F II : krim pewarna rambut ekstrak daun jati dengan konsentrasi $12,5 \%$

F III : krim pewarna rambut ekstrak daun jati dengan konsentrasi 15\%

\section{3. Uji Stabilitas Metode Cycling Test}

Pengamatan organoleptis menunjukkan bahwa bentuk dan bau dari ke tiga formula setelah cycling test selama 6 siklus mengalami perubahan dimana warna sediaan ketiga formula mengalami perubahan dari pekat menjadi lebih pucat. Perubahan warna sediaan tersebut dikarenakan pada suhu tinggi, antosianin mengalami perubahan struktur/ dekomposisi dengan 2 tahap yaitu pertama terjadi hidrolisis ikatan glikosidik antosianin yang menghasilkan aglikon yang tidak stabil, kemudian cincin aglikon terbuka membentuk gugus karbinol dan kalkon yang tidak berwarna sehingga stabilitas warna antosianin menurun dan terjadinya pemucatan warna $(21 ; 22)$. Selain itu faktor suhu tinggi pada pemanasan menyebabkan stabilitas warna antosianin rendah dikarenakan terjadinya kerusakan gugus kromofor sehingga menyebabkan kerusakan warna (23).

Hasil uji pH (tabel 4) menunjukkan sediaan krim pewarna rambut ada perbedaan yang bermakna antar siklus cycling test $(\mathrm{P}<0.005)$. Kemudian dilanjutkan dengan Post hoc Test Tukey untuk mengetahui perbedaan tersebut. Diperoleh adanya perbedaan yang bermakna antar semua siklus kecuali pada siklus 1 terhadap siklus 2; siklus 2 terhadap siklus 1; siklus 3 terhadap siklus 4 dan siklus 4 terhadap siklus 3 tidak terdapat perbedaan yang bermakna. Untuk semua formula nilai $\mathrm{pH}$ tetap memenuhi persyaratan $\mathrm{pH}$ sediaan untuk rambut.

Nilai viskositas sediaan krim pewarna rambut (tabel 6) pada FI, FII, dan FIII setelah cycling test menjadi cenderung lebih cair. Hal tersebut dikarenakan suhu panas yang diperoleh sediaan krim akan memperbesar jarak antara atom sehingga 
gaya antar atom menjadi berkurang, kemudian jarak yang merenggang tersebut menyebabkan viskositas krim menurun (24).

Tabel 4 Hasil Uji pH Krim setelah Cycling Test

\begin{tabular}{|c|c|c|c|}
\hline \multirow{2}{*}{ Siklus } & \multicolumn{3}{|c|}{ pH rata-rata \pm SD } \\
\cline { 2 - 4 } & FI & FII & FIII \\
\hline $\mathbf{0}$ & $6,297 \pm 0,118$ & $6,770 \pm 0,010$ & $5,917 \pm 0,045$ \\
\hline $\mathbf{1}$ & $6,230 \pm 0,010$ & $5,943 \pm 0,046$ & $5,813 \pm 0,057$ \\
\hline $\mathbf{2}$ & $6,206 \pm 0,042$ & $5,873 \pm 0,032$ & $5,647 \pm 0,055$ \\
\hline $\mathbf{3}$ & $6,053 \pm 0,021$ & $5,697 \pm 0,051$ & $5,447 \pm 0,061$ \\
\hline $\mathbf{4}$ & $5,990 \pm 0,030$ & $5,687 \pm 0,038$ & $5,403 \pm 0,107$ \\
\hline $\mathbf{5}$ & $5,797 \pm 0,040$ & $5,477 \pm 0,025$ & $5,210 \pm 0,040$ \\
\hline $\mathbf{6}$ & $5,697 \pm 0,206$ & $5,240 \pm 0,061$ & $5,077 \pm 0,059$ \\
\hline
\end{tabular}

Hasil analasis dengan Two Way Anova. menunjukkan adanya perbedaan yang bermakna hasil viskositas pada siklus cycling test $(\mathrm{P}<0.005)$. Kemudian dilanjutkan dengan Post hoc Test Tukey untuk mengetahui perbedaan tersebut. Hasil cycling test diperoleh adanya perbedaan antara siklus 0 terhadap siklus 2, 3 dan 5; siklus 1 terhadap siklus 2 dan 5 ; siklus 2 terhadap siklus siklus 0 dan 1 ; siklus 3 terhadap siklus 0 ; siklus 5 terhadap siklus 0,1 , dan 6; serta siklus 6 terhadap siklus 5 .

Hasil uji daya sebar (tabel 6) tidak terdapat perbedaan bermakna antar siklus test $(\mathrm{P}>0.005)$ sehingga dapat dikatakan perubahan suhu tidak berpengaruh terhadap daya sebar krim ekstrak daun jati.

\section{4. Pengujian Pewarnaan Terhadap Rambut}

Hasil pengamatan subjektif, Krim pewarna rambut ekstrak daun jati memberikan warna coklat kemerahan terhadap rambut. Hal ini dikarenakan pada ekstrak daun jati terdapat senyawa antosianin yang merupakan senyawa fenol yang tersubstitusi oleh gugus glukosida dan mempunyai gugus kromofor (25). Adanya ikatan rangkap terkonjugasi pada gugus kromofor yang terdapat dalam struktur antosianin membuat antosianin dapat menyerap cahaya pada daerah sinar tampak sehingga antosianin jenis sianidin memberikan warna oranye - merah (26).

Tabel 5. Hasil Uji Viskositas Krim setelah Cycling Test

\begin{tabular}{|c|c|c|c|}
\hline \multirow{2}{*}{ Siklus } & \multicolumn{3}{|c|}{ Viskositas rata-rata (cPs) \pm SD } \\
\cline { 2 - 4 } & FI & FII & FIII \\
\hline $\mathbf{0}$ & $11.400 \pm 268,514$ & $11.463 \pm 501,232$ & $11.687 \pm 283,078$ \\
\hline $\mathbf{1}$ & $11.537 \pm 402,782$ & $11.227 \pm 509,640$ & $11.280 \pm 310,000$ \\
\hline $\mathbf{2}$ & $10.789 \pm 1188,606$ & $10.294 \pm 386,714$ & $10.001 \pm 208,857$ \\
\hline $\mathbf{3}$ & $10.867 \pm 480,867$ & $10.620 \pm 229,129$ & $9.819 \pm 747,105$ \\
\hline $\mathbf{4}$ & $11.323 \pm 430,852$ & $10.523 \pm 386,825$ & $10.563 \pm 983,515$ \\
\hline $\mathbf{5}$ & $10.727 \pm 684,130$ & $9.660 \pm 222,243$ & $9.998 \pm 479,804$ \\
\hline $\mathbf{6}$ & $11.563 \pm 35,119$ & $10.988 \pm 984,902$ & $11.121 \pm 881,037$ \\
\hline
\end{tabular}


Tabel 6. Hasil Uji Daya Sebar Krim Ekstrak Daun Jati Setelah Cycling Test

\begin{tabular}{|c|c|c|c|}
\hline \multirow{2}{*}{ Siklus } & \multicolumn{3}{|c|}{ Daya Sebar rata-rata (cm) \pm SD } \\
\cline { 2 - 4 } & FI & FII & FIII \\
\hline $\mathbf{0}$ & $5,326 \pm 0,303$ & $5,072 \pm 0,760$ & $5,050 \pm 0,092$ \\
\hline $\mathbf{1}$ & $5,271 \pm 0,708$ & $5,000 \pm 0,039$ & $4,667 \pm 0,194$ \\
\hline $\mathbf{2}$ & $5,221 \pm 0,296$ & $5,131 \pm 0,608$ & $5,080 \pm 0,398$ \\
\hline $\mathbf{3}$ & $5,288 \pm 0,201$ & $5,013 \pm 0,406$ & $4,817 \pm 0,105$ \\
\hline $\mathbf{4}$ & $5,433 \pm 0,269$ & $5,192 \pm 0,390$ & $4,775 \pm 0,187$ \\
\hline $\mathbf{5}$ & $5,254 \pm 0,425$ & $5,071 \pm 0,344$ & $4,758 \pm 0,101$ \\
\hline $\mathbf{6}$ & $5,567 \pm 0,388$ & $5,096 \pm 0,535$ & $4,883 \pm 0,383$ \\
\hline
\end{tabular}

Penilaian objektif dilakukan dengan cara mengukur intensitas warna menggunakan alat colour reader $C R-10$. Alat tersebut mengukur intensitas warna dengan menggunakan sistem warna Hunter yaitu menghasilkan 3 parameter yaitu koordinat L, a*, dan b*. Notasi L*: 0 (hitam); 100 (putih) menyatakan cahaya pantul yang menghasilkan warna akromatik putih, abu-abu dan hitam. Notasi a*: warna kromatik campuran merah-hijau dengan nilai $+a^{*}$ (positif) dari 0 sampai +80 untuk warna merah dan nilai -a* (negatif) dari 0 sampai -80 untuk warna hijau. Notasi b*: warna kromatik campuran biru-kuning dengan nilai $+b^{*}$ (positif) dari 0 sampai +70 untuk warna kuning dan nilai -b* (negatif) dari 0 sampai -70 untuk warna biru . Hasil pengukuran intensitas warna dapat dilihat di tabel 7.

Tabel 7. Hasil Pengukuran Warna Krim Ekstrak Daun Jati

\begin{tabular}{llll}
\hline Formula & L & a & B \\
\hline FI & 21,267 & $-7,567$ & $+11,867$ \\
FII & 20,267 & $-7,267$ & $+10,667$ \\
FIII & 19,4 & $-7,767$ & $+9,900$ \\
\hline
\end{tabular}

Pada pengolahan data warna ini ini akan menunjukan perbedaan warna dari krim pewarna rambut ekstrak daun jati yang dihasilkan. Nilai $L^{*}$ pada formulasi krim pewarna rambut ekstrak daun jati pada setiap formulasi semakin menurun atau semakin mendekati nilai 0 yang artinya warna krim pewarna rambut semakin gelap. Hal ini dikarenakan konsentrasi ekstrak yang digunakan. Semakin tinggi konsentrasi ekstrak yang digunakan, maka warna yang dihasilkan akan lebih gelap atau pekat. Berdasarkan nilai a* pada FI, FII dan FIII menunjukkan formulasi krim ekstrak daun jati cenderung memiliki warna kromatik hijau. Nilai b* pada formulasi krim ekstrak daun jati cenderung memiliki warna kromatik kuning.

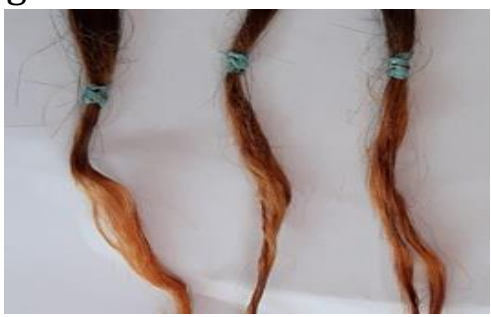

\section{Gambar 4. Hasil Pewarnaan Rambut Dengan Krim Ekstrak Daun Jati}




\section{KESIMPULAN}

Berdasarkan hasil penelitian dan pembahasan yang telah dipaparkan, maka dapat ditarik kesimpulan sebagai berikut :

1. Ekstrak daun jati mempunyai efektivitas sebagai pewarna rambut alami yang menghasilkan warna coklat kemerahan.

2. Ekstrak daun jati dapat diformulasikan sebagai krim pewarna rambut alami dan memenuhi uji sifat fisik sediaan krim.

3. Hasil uji Cycling test menunjukan ketidakstabilan warna dari krim pewarna rambut.

\section{DAFTAR PUSTAKA}

(1) Hamman, D. (2014). $p$-Phenylenediamine and Other Allergens in Hair Dye Products in The United States: A Consumer Exposure Study. Contact Dermatitis. 70: 213-218.

(2) Vogel, A. T., et al. (2015). p-Phenylenediamine Exposure in Real Life - A CaseControl Study on Sensitization Rate, Mode and Elicitation Reactions in The Northern Netherlands. Contact Dermatitis. 72: 355-361.

(3) Zaky, M., Susanti, T. R., Pratiwi, D. (2015). Pengembangan Formulasi dan Uji Evaluasi Fisik Sediaan Pewarna Rambut Ekstrak Biji Pinang (Areca Catechu L.) sebagai Pewarna Alami. Farmagazine. 2(1). 35-43.

(4) Nurwanti, M., Budiono, J. D., Pratiwi, R. (2013). Pemanfaatan Filtrat Daun Muda Jati sebagai Bahan Pewarna Alternatif dalam Pembuatan Preparat JaringanTumbuhan. BioEdu. 2(1).

(5) Baharuddin, A., Saokani, A. J., Risnah, I. A. (2015). Karakteristik Zat Warna Daun Jati (Tectona grandis) Fraksi Metanol : n-Heksana sebagai Photosensitizer pada Dye Sensitized Solar Cell. Chemica et Natura. 3(1): 37-41.

(6) Sulaksana, J. (2005). Kemuning dan Jati Belanda dan Pemanfaatan untuk Obat.Penebar Swadaya, Jakarta.

(7) Rosyida, A., Achadi, D. (2014). Pemanfaatan Daun Jati Muda untuk Pewarnaan Kain Kapas pada Suhu Kamar. Arena Tekstil. 29(2): 115-124.

(8) Pratama, Y. 2013. Pemanfaatan Ekstrak Daun Jati (Tectona grandis Linn. F.)sebagai Indikator Titrasi Asam-Basa. Skripsi. Semarang. Fakultas Matematika dan Ilmu Pengetahuan Alam, Universitas Negeri Semarang.

(9) Arofiani, Neni. 2015. Penggunaan Ekstrak Pucuk Daun Jati (Tectona grandis L.f) sebagai Pewarna Rambut. Skripsi. Sumatera Utara : Universita Sumatera Utara

(10) Latirah. Indrawati, T., Purba, A. V. (2015). Pengembangan Pewarna Rambut dariEkstrak Kental Gambir (Uncaria gambir Roxb.) dalam Sediaan Setengah Padat. Jurnal Ilmu Kefarmasian Indonesia. 13(1): 89-93.

(11) Januarti, I. B., Santoso, A., Razak, A. S. (2017) . Ekstraksi Senyawa Flavonoid Daun Jati (Tectona grandis L.) Dengan Metode Ultrasonik (Kajian Rasio Bahan : Pelarut Dan Lama Ekstraksi). Media Farmasi Indonesia. 12 (2).

(12) Lestari, P. P., Kusrini, D., Anam, K. (2014). Anthocyanin Identification of Methanol-HCl Extract Active Fraction in Rosella (Hibiscus Sabdariffa.L) 
and Its Potential as Xanthine Oxidase Inhibitor. Jurnal Sains dan Matematika. 22 (3): 72-78.

(13) Sanja, T. 2011. Uji Sifat Fisis Gel Antiacne Ekstrak Etanol Gambir (encaria gambir) Dalam Basis Na alginate \& Uji Aktivitas Antibakteri Terhadap Staphylococcus auereus. Purwokerto. Fakultas Farmasi, Universitas Muhammadiyah Purwokerto.

(14) Aji, P. B. 2012. Formulasi Krim Ekstrak Etanol Daun Ketepeng Cina dan Uji Aktivitas Antifungsinya Terhadap Trichophyton Meniagrephtes. Skripsi. Purwokerto. Fakultas Farmasi, Universitas Muhammadiyah Purwokerto.

(15) Lubis, E. S. dan Reveny, J. (2012). Pelembab Kulit Alami Dari Sari Buah Jeruk Bali [ Citrus maxima (Burm.) Osbeck ] Natural Skin Moisturizer From Pomelo Juice [Citrus maxima (Burm.) Osbeck ]. Journal of Pharmaceutics and Pharmacology. 1(2):104-111.

(16) Rieger, M. (2000). Harry's Cosmeticology (8th Edition). New York: Chemical Publishing Co Inc.

(17) Sholihah, M. 2016. Ultrasonic-Assisted Extraction antioksidan Dari Kulit Manggis. Tesis. Bogor. Sekolah Pascasarjana, Institut Pertanian Bogor.

(18) Mandal, S.C., Mandal, V. dan Das, A.K. (2015). Essentials of Botanical Extraction : Principles and Application. Elsevier.

(19) Markham, K. R. (1982). Techniques Of Flavonoid Identification. Bandung : Penerbit ITB.

(20) Alfath, A., M. 2012. Formulasi Krim Ekstrak Etanolik Buah Mahkota Dewa (Phaleria Macrocarpa (Scheff) Boerl.) Dengan Basis A/M Dan M/A. Skripsi. Surakarta. Fakultas Farmasi, Universitas Muhammadiyah Surakarta.

(21) Markakis,P. (1982). Anthocyanins as Food Colors. NewYork : Academic Press.

(22) Winarti S. dan Firdaus A., (2010). Stabilitas Warna Merah Ekstrak Bunga Rosela Untuk Pewarna Makanan Dan Minuman. Surabaya. Jurnal Teknologi Pertanian. 1(2). 87-93.

(23) Hidayah, T. 2013. Uji Stabilitas Pigmen Dan Antioksidan Hasil Ekstraksi Zat Warna Alami Dari Kulit Buah Naga (Hylocereus undatus). Skripsi. Semarang. Fakultas Matematika dan Ilmu Pengetahuan Alam, Universitas Negeri Semarang.

(24) Alfred, M. (1993). Farmasi Fisika Edisi 3. Jakarta : Universitas Indonesia.

(25) Anggraini, A. 2016. Aplikasi Antosianin Dari Kubis Merah (Brassica oleracea.var. capitata L.f.rubra) Sebagai Senyawa Kemosensor Anion. Skripsi. Yogyakarta. Fakultas Matematika dan Pengetahuan Alam, Universitas Gadjah Mada.

(26) Priska, M., et al. 2018. Review: Antosianin Dan Pemanfaatannya. Cakra Kimia (Indonesian E-Journal of Applied Chemistry). 6 (2) :2302-7274. 